\title{
The early book herbaria of Leonhard Rauwolf (S. France and N. Italy, 1560-1563): new light on a plant collection from the 'golden age of botany'
}

\author{
Anastasia Stefanaki ${ }^{1,2,3}$ (D) Tilmann Walter ${ }^{4} \cdot$ Henk Porck $^{5} \cdot$ Alice Bertin $^{1} \cdot$ Tinde van Andel $^{1,2,6}$
}

Received: 18 January 2021 / Accepted: 21 June 2021 / Published online: 10 July 2021

(C) The Author(s) 2021

\begin{abstract}
The sixteenth century was a golden age for botany, a time when numerous naturalists devoted themselves to the study and documentation of plant diversity. A very prominent figure among them was the German physician, botanist, and traveler Leonhard Rauwolf (1535?-1596), famous for his travel account and luxurious book herbarium containing plants from the Near East. Here, we focus on the less studied, early book herbaria of Rauwolf. These form a three-volume plant collection bound in leather and gold, which contains over 600 plants that Rauwolf collected between 1560 and 1563 in S. France and N. Italy when he was a student of medicine. We show the botanical value of Rauwolf's early book herbaria, exemplified by two exotic American specimens, namely one of the oldest surviving specimens of tobacco (Nicotiana rustica), collected in Italy, and the oldest known French record of prickly pear (Opuntia ficus-indica). These well-preserved specimens indicate that Rauwolf was eager to collect exotic plants already in his early botanical steps. We further discuss Rauwolf's professional botanical network during his student years and suggest that the famous Swiss botanist Johann Bauhin (1541-1613), friend and companion of Rauwolf during his field excursions and their medical studies in Montpellier, has played a significant role in the compilation of this precious historical plant collection. We also show that Leonhart Fuchs (and not Carolus Clusius) extensively annotated the three book herbaria. Finally, we reconstruct the story of making of the book herbaria, as evidenced through observations of paper watermarks and handwritten texts in the book volumes, and show that all four book herbaria of Rauwolf were probably bound between 1577 and 1582 .
\end{abstract}

Keywords History of Botany $\cdot$ Historical collections $\cdot$ Tobacco $\cdot$ Opuntia $\cdot$ Johann Bauhin $\cdot$ Leonhart Fuchs

\section{Introduction}

Anastasia Stefanaki

anastasia.stefanaki@gmail.com

1 Naturalis Biodiversity Center, National Herbarium of the Netherlands, Leiden, The Netherlands

2 Biosystematics Group, Wageningen University, Wageningen, The Netherlands

32019 Van de Sande Fellow, Scaliger Institute, Leiden University Library, Leiden, The Netherlands

4 Institut Für Geschichte Der Medizin, Julius-Maximilians-Universität Würzburg, Würzburg, Germany

5 Curator Emeritus of the Paper History Collection, National Library of The Netherlands, The Hague, The Netherlands

6 Clusius Chair of History of Botany and Gardens, Leiden University, Leiden, The Netherlands
During the sixteenth century, numerous scholars across Europe devoted themselves to the documentation, description, collection, and preservation of the natural world (Ogilvie 2006; Cooper 2007). Turning to nature in search for the plants described in antiquity, these sixteenth century naturalists discovered new plants, unknown to the ancient authors, and attempted for the first time in history to catalogue all then known species (Ogilvie 2006; Cooper 2007; Egmond 2018). They carried out field expeditions to collect plants, press-dried and glued them on paper sheets, compiling the oldest book herbaria that survive today. It was through these processes that botany diverged from a medicinal practice into a scientific discipline of its own (Stefanaki et al. 2019). In this so-called botanical Renaissance of the sixteenth century, no other naturalist exhibited the adventurous and 
pioneering spirit of the German physician, botanist, and traveler Leonhard Rauwolf (1535?-1596).

Rauwolf was born in Augsburg, a bustling merchant city in southern Germany, from a middle class family of iron traders. Later he became famous as the first early modern European to travel to the Near East up to Baghdad in search for new medicinal plants (Walter 2009; Ghorbani et al. 2018). This hazardous journey that lasted 3 years (1573-1576) is documented in detail in Rauwolf's printed travel account (Rauwolf 1583). This book was to become a bestseller at its time, having been published in multiple editions and translations (Walter 2009; Ghorbani et al. 2018). In the first lines of his travelogue, Rauwolf finely outlines the concept of sixteenth century botany, expressing his keen interest, since very early in his life, in the plants described by the ancient Greek and Arabic authors. He expresses his intention to acquire knowledge on these plants and see them in their native habitats in the Mediterranean. He also reports that the tales of Augsburg merchants had awakened in him the desire to travel (Rauwolf 1583). The output of this profound, life-long desire was a large collection of almost 900 dried plant specimens from France, Italy, Lebanon, Syria and today's Iraq bound in four book volumes.

Long before reaching fame as a traveler to the Near East, Rauwolf started the compilation of his plant collection while a young student of medicine. After a short time at the universities of Tübingen (1554) and Wittenberg (1556), he went to the medical university of Montpellier (Ganzinger 1963; Dannenfeldt 1968) (Fig. 1). There, from 1560 to 1562, he studied medicine as a student of the famous botanist, and pupil of Luca Ghini, Guillaume Rondelet (1507-1566) (Dannenfeldt 1968). During his student years, Rauwolf eagerly botanized in the surroundings of Montpellier, and also around Languedoc, Provence, Auvergne, and Rhône Alpes. The plants he collected formed the first two books of his plant collection. Rauwolf graduated in 1562 from the University of Valence, Dauphiné (Dannenfeldt 1968). In 1563, he carried out his peregrinatio academica traveling through the Alps to $\mathrm{N}$. Italy. On the way, he collected the plants that formed the third book herbarium. Rauwolf visited Padua, Verona, Mantua, Ferrara, Bologna, Florence, Modena, Piacenza, Parma, Milan, and Como, heading forward through Switzerland to Germany. During this homeward journey, Rauwolf visited Conrad Gessner (1516-1565) in Zurich, accompanied by his friend and classmate from Montpellier, Johann Bauhin (1541-1613) (Durling 1965). According to Legré (1900), that same year, Rauwolf met in Augsburg with Carolus Clusius (1526-1609), to which he presented the plants he had collected in France and Italy, and presumably accepted Clusius' annotations and corrections of several plant names. Doubting Legré's argument, Ganzinger (1963) attributed the numerous annotations and corrections found in Rauwolf's herbaria to Leonhart Fuchs (1501-1566), suggesting that Rauwolf, on his way back to Augsburg in 1563, also visited Fuchs, his former teacher in Tübingen. Ganzinger (1963) also observed that Fuchs had marked several plants with the phrase 'Soll gerissen werden', an indication to illustrator Jerg Ziegler to draw these plants for Fuchs' upcoming herbal (Seybold 1990; Kusukawa 2006). The latter was an impressive collection of over 1500 plant illustrations that remained unfinished due to Fuchs' death and only saw the light of publication in 2001 (Baumann et al. 2001).

In 1571, Rauwolf was appointed city physician of Augsburg, a position that he, as a devoted Protestant, lost 17 years later due to religious conflicts. For the city council had dismissed the old preachers who had found favor in the congregations and appointed new ones, an act of arbitrariness against which Rauwolf and others protested (Herde and Walter 2010). Thereby getting into financial difficulties, he decided to sell his herbaria, which he achieved for a remarkable price, 310 Reichstaler, which had to be paid to Rauwolf by the imperial chamber. The four book herbaria were bought in 1593 by a commissioner of the Habsburg Emperor Rudolf II (1552-1612) and became part of Rudolf's famous

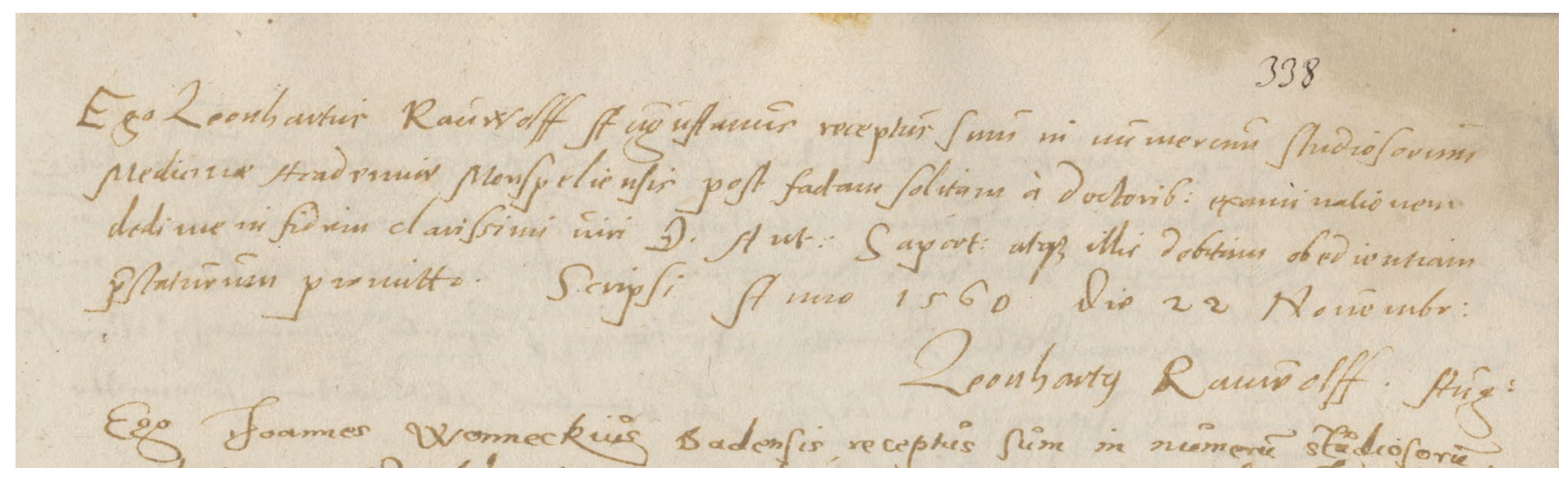

Fig. 1 Matriculation oath of Leonhard Rauwolf at the University of Montpellier in 1560. Credit: BIU de Montpellier. Service photographique 
collections in Prague (Callmer 1973; Walter et al. 2021). They were later stolen by Swedish troops, and, together with the Italian En Tibi herbarium, which was also part of Rudolf's cabinet of curiosities, they were brought to Stockholm and handed to Queen Christina of Sweden (Callmer 1973; Stefanaki et al. 2019). There they came to the possession of the Dutch librarian Isaac Vossius (1618-1689). When Vossius died, his heirs sold Vossius' collection of books to Leiden University and the book herbaria finally came in 1690 to Leiden, where they are preserved to this day. The first herbarium is on display at the Boerhaave museum, and the remaining three herbaria are kept in the treasure room of Naturalis Biodiversity Center.

The botanical content of the fourth volume comprising the plants that Rauwolf collected in the Near East was recently studied by Ghorbani et al. $(2017,2018)$. Our work focuses on the first three volumes of Rauwolf's plant collection (hereafter Rauwolf's early book herbaria), compiled during his student years. Unlike Rauwolf's travels to the Near East, this early period of Rauwolf's botanical activity is hardly known. According to Dannenfeldt (1968) and Herde and Walter (2010), the best historical source for the travels of Rauwolf in France and Italy is Rauwolf's herbaria themselves, which have remained to date largely unexplored. Several attempts by J.G. Boerlage (1849-1900), former staff member of the Rijksherbarium in Leiden, to catalogue and identify the specimens of the book herbaria, have remained incomplete (Naturalis archives). Part of the botanical contents of the first and the second herbarium were published by Legré (1900), but the plant specimens of the third volume were never studied. Images of specimens contained in the herbaria have been published by Thijsse (2016), Stech et al. (2018) and Stefanaki and van Andel (2021). A full inventory of the plant species included in the herbaria is in preparation by some of the authors of this article. Here, we present some exotic specimens contained in the herbaria, discuss the professional botanical network of Rauwolf in the period when the herbaria were compiled, and elucidate the history of compilation of this precious historical plant collection.

\section{Materials and methods}

To demonstrate the botanical value of Rauwolf's early book herbaria, we focused on two specimens of exotic species, namely Nicotiana rustica L. (tobacco) collected in Italy, and Opuntia ficus-indica (L.) Mill. (prickly pear) collected in France. We searched for specimens of these two species in other surviving sixteenth century book herbaria from Italy, France and other European countries, namely the herbaria of U. Aldrovandi (Soldano 2000, 2001, 2002, 2003, 2004, 2005), A. Cesalpino (Caruel 1858), M. Merini (Chiovenda 1927), J. Girault (images of its index provided by the National Museum of Natural History, Paris), C. Bauhin (https://herbarium.unibas.ch), F. Platter (https://www.burge rbib.ch/de/bestaende/privatarchive/einzelstuecke/platterherbarium), C. Ratzenberger (Kessler 1870), H. Harder (Speta and Grims 1980; http://daten.digitale-sammlungen. de/ db/0001/bsb00011834/images/), the Erbario Ducale Estense (Camus and Penzig 1885), the En Tibi herbarium (Stefanaki et al. 2018) and Erbario A and B (Penzig 1905).

To explore the botanical network of Rauwolf in the period of compilation of his early book herbaria, we identified the naturalists who contributed handwritings in the three book volumes. For this, we compared the handwritings of plant names, descriptions and annotations found next to the plant specimens and in the indices with samples of the handwriting of Rauwolf and that of other sixteenth century naturalists that are reported to have been connected to Rauwolf in the 1560s. These are (i) Carolus Clusius, of which we used autograph letters to various recipients held at the Special Collections of Leiden University Library, the Trew collection (www.trew-letters.com), and Clusius' correspondence: a digital edition-in-progress (https://clusiuscorrespondence. huygens.knaw.nl/edition/); (ii) Leonhart Fuchs, of which we used two autograph letters to Joachim Camerarius the Elder, dated 24 November 1565 (http://gateway-bayern.de/BV044 375082), and 27 May 1543 (Stübler 1928); (iii) Conrad Gessner (two autograph letters, to Hieronymus Frobenius dated 15 January 1561 and to Georg Cassander dated 09 October 1562, both held at the Special Collections of Leiden University Library), and (iv) Johann Bauhin (six autograph letters to Joachim Camerarius sent between 1578 and 1597, available from the University Library of Erlangen-Nuremberg, https://ub.fau.de/). For the handwriting of Rauwolf, we used two autograph letters, to Joachim Camerarius dated 27 March 1579 (http://gateway-bayern.de/BV043447612) and to Carolus Clusius dated 06 September 1584 (Special Collections, Leiden University Library; https://clusiuscorrespo ndence.huygens.knaw.nl/edition/entry/1428).

To elucidate the history of making of Rauwolf's early book herbaria, we transcribed and translated the calligraphic text of the title pages of the three book volumes, and carried out observations of the watermarks and characteristics of the paper by means of transmitted light, using a thin, flexible electroluminescence sheet. We attempted to trace the watermarks found in the three books in the catalogue of the Memory of Paper database of the Bernstein project, www. memoryofpaper.eu/BernsteinPortal.

\section{Results and discussion}

The three early book herbaria of Rauwolf are large $(32 \times 21.5 \mathrm{~cm})$, leather-bound volumes, which can be closed with metal, copper-colored clasps. Although several 


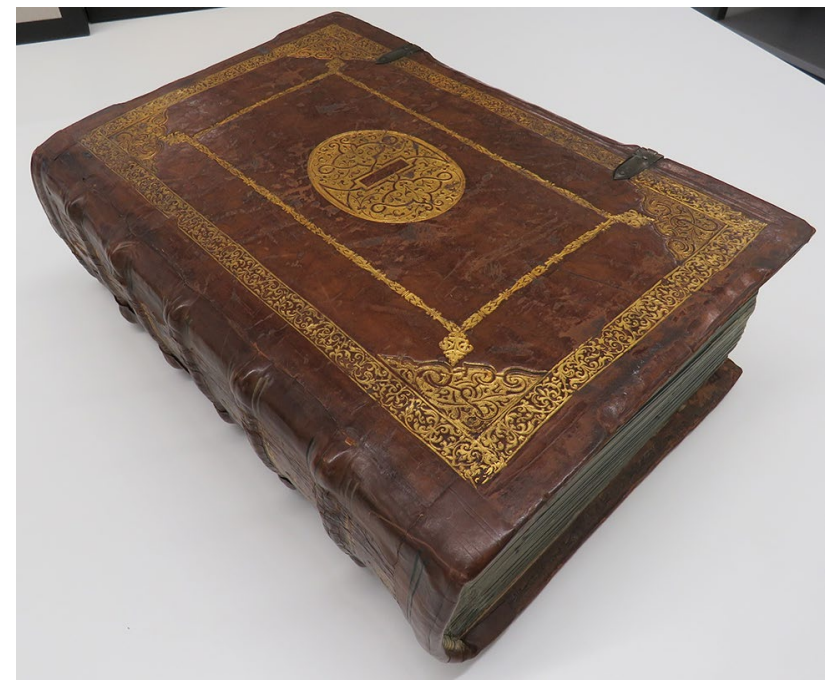

Fig. 2 The second book herbarium compiled in S. France

conservation treatments have been performed in the past, the bindings are still mainly in their original state. The leather on the boards and the spine of the books show gold embossed decorations (Fig. 2). The three books have the same content arrangement, each one consisting of a calligraphic title page (Fig. 3; Table 1), followed by more than 200 plant specimens glued on both sides of the paper sheets, and an ascending index of plant names at the back of each book (Fig. 4). Strips of green-colored paper, decorated with silver embossed motifs are found attached to all margins of the herbarium sheets. These strips were added to protect the plant specimens from abrading each other. The strips were probably added by the book binder, as their embossed decoration appears to have been made by means of a roll, a known stamp tool in the bookbinder's workshop.

The three book herbaria demonstrate Rauwolf's skills as a botanist and his special interest in foreign species, hitherto largely unknown. The first and second herbaria contain mainly native species of S. France. The third herbarium mostly contains plants native to N. Italy and the Alps, and some exotic species. A number of plants contained in the third herbarium have been collected in Switzerland and Germany (Table 1).

\subsection{Tobacco}

Among the New World plants that are present in the book herbaria, we find a specimen of tobacco, Nicotiana rustica L., which Rauwolf collected in Italy in 1563 (Fig. 5). $N$. rustica is an Andean species that was cultivated by $\mathrm{N}$. American colonists before common tobacco, N. tabacum, but was replaced by the latter because $N$. tabacum was preferred by European importers (Lewis 2011). N. rustica is distinguished morphologically from common tobacco by its

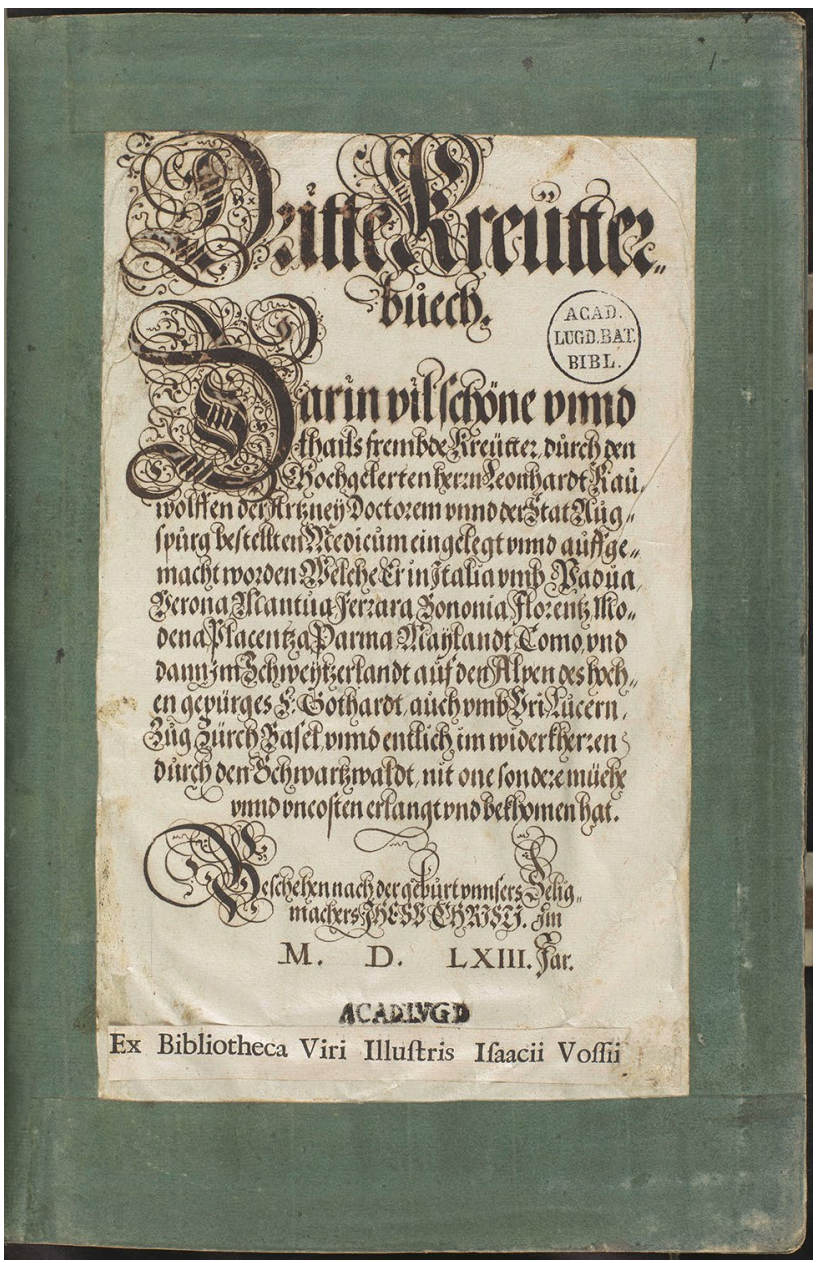

Fig. 3 Title page of the third book herbarium compiled in N. Italy

yellow flowers with wider corolla tubes slightly exceeding the calyx (Knapp et al. 2004). According to Meyer et al. (1999), N. rustica was first introduced in the Low Countries in the mid-1540s. In 1558, it was brought from Flanders to Portugal (Meyer et al. 1999), and according to De Toni (1940), through Portugal, it reached Italy around 1561 . However, this latter introductory step might refer to $N$. tabacum (Vicentini et al. 2020a and references therein). Possibly, $N$. rustica was already cultivated in Italy the decade before, as Gessner remembers that in 1554 he had received seeds from either France or Italy (Kusukawa 2012). Since these statements are uncertain, we can at least infer from the fact that Rauwolf acquired his specimen during his visit to Italy in 1563 that $N$. rustica was most likely cultivated by that year in the country. Rauwolf knew tobacco already from France, as he calls it 'Priapeïa', a name apparently used for N. rustica by Rondelet (Kusukawa 2012), Rauwolf's teacher in Montpellier. Besides the Rauwolf herbaria, the only Italian sixteenth century collection that contains specimens of $N$. rustica is the herbarium of Aldrovandi: one specimen from 


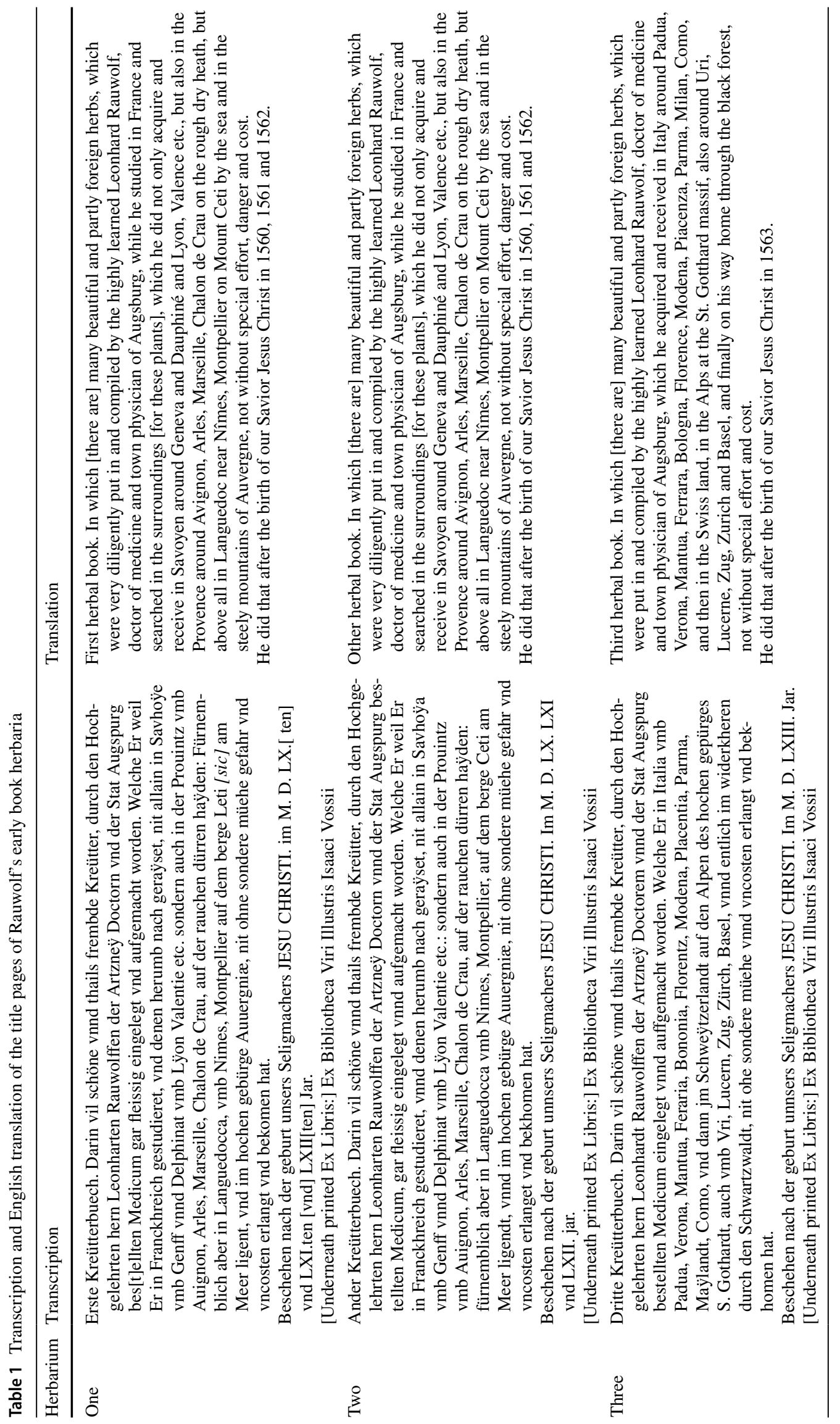




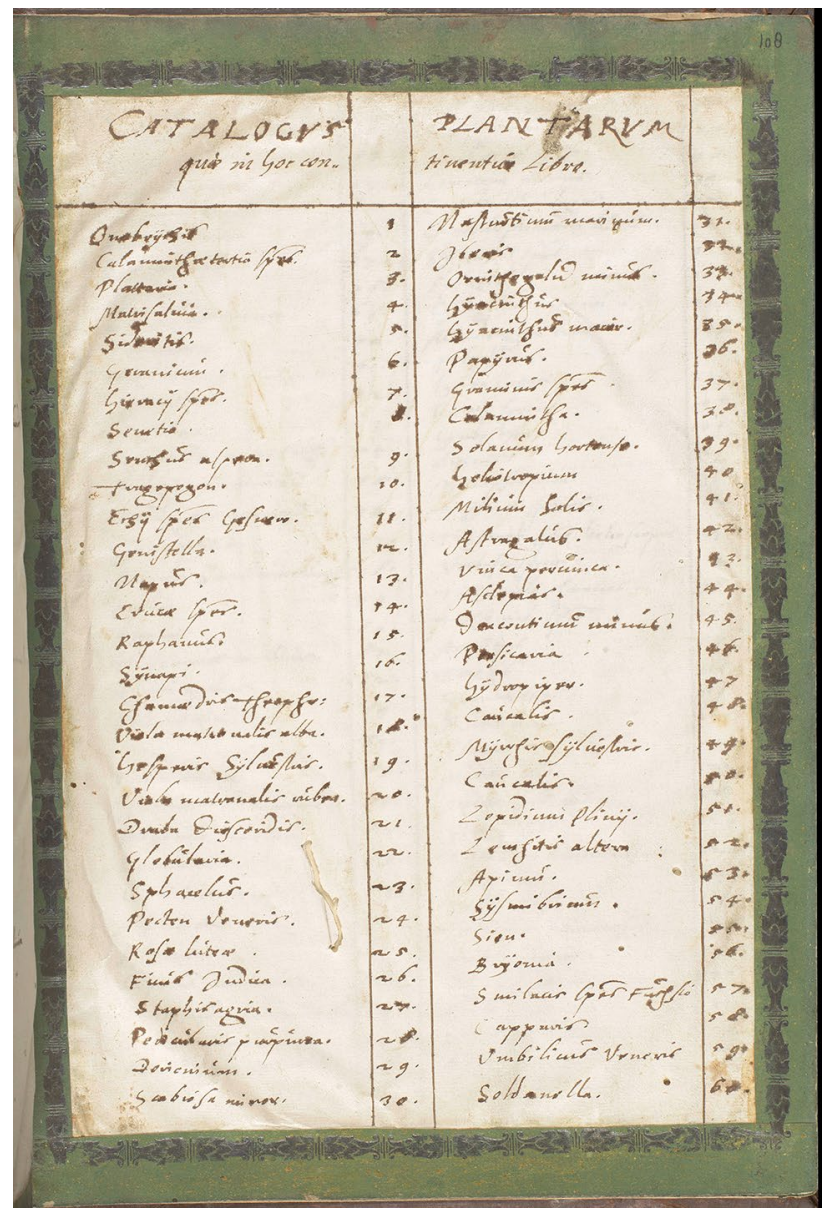

Fig. 4 The index of the first book herbarium compiled in S. France

c. 1554-1560 is named as 'Hyosciamus Gallicus' (Soldano 2003) implying a French provenance, and a second specimen (c. 1563-1568) did not come from a plant grown in Italian ground, but was sent to Aldrovandi from Jean de Brancion from Mechelen, Flanders (Soldano 2004). Three specimens of $N$. tabacum included in the Aldrovandi herbarium are all of Italian provenance and dated c. 1565-1580 (Soldano 2004), and one specimen contained in the Erbario Estense is dated 1570-1598 (Camus and Penzig 1885; Vicentini et al. 2020a, b). A plant specimen named 'Priapeia' in the French Girault herbarium (1558) probably belongs to either N. rustica or N. tabacum. Other early tobacco specimens are found in German herbaria compiled later in the sixteenth century (Ratzenberger, 1592: N. rustica, N. tabacum; Harder, c. 1576-1594: N. tabacum, c. 1599: N. rustica, N. tabacum).

\subsection{Prickly pear}

Another interesting exotic plant included in Rauwolf's early book herbaria is a specimen of prickly pear or Indian fig, Opuntia ficus-indica (L.) Mill. This specimen, consisting

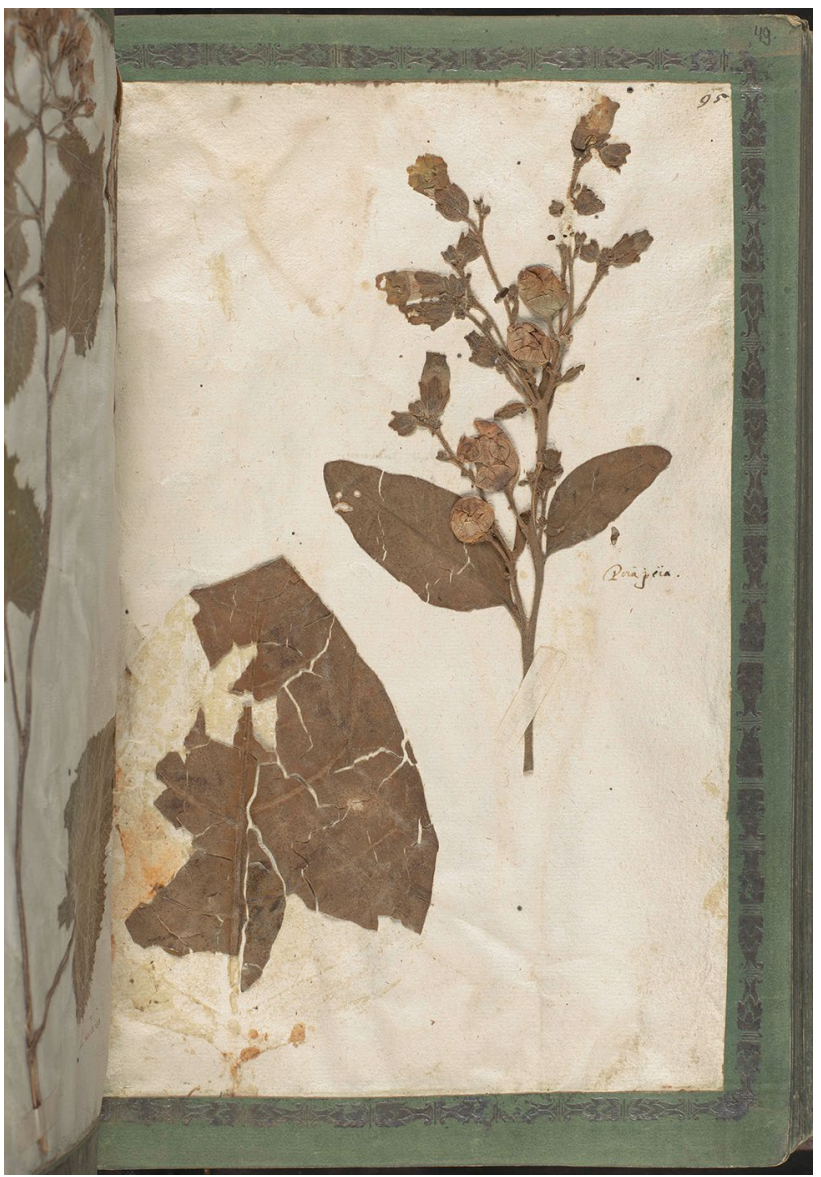

Fig. 5 Specimen of tobacco, Nicotiana rustica L., from the third book herbarium (N. Italy, 1563)

of a large leaf and a flower, shows the excellent specimen preparation technique of Rauwolf, with the succulent tissue carefully removed and the skin without spines firmly glued on the paper (Fig. 6). There is textual evidence that Rauwolf was also horticulturally familiar with Opuntia: on 10 May 1581, Johann Aicholz ( $†$ 1588), professor of medicine and Clusius' landlord in Vienna, reported to his Nuremberg colleague Camerarius that he had received instructions on how to care for his 'Opuntia' from Rauwolf (http://gateway-bayern.de/BV043425098). This Mesoamerican species, which Rauwolf collected between 1560 and 1562 in S. France, was probably first introduced to Seville, Spain (Casas and Barbera 2002). It was observed growing wild in Rome, Italy, as early as 1549 by Johannes Kentmann, but was still unknown to local physicians (Eggli et al. 2018). Kentmann made an illustration of prickly pear and reported the later testimony of a Venetian apothecary that this plant was abundant in the Indies where it produced small sweet figs, and therefore, it was then named by Italians as Indian fig (Kentmann 1549). One year later, in 1550, Aldrovandi also reported seeing the plant in Rome (Soldano 2000), and in 1553, he included two 


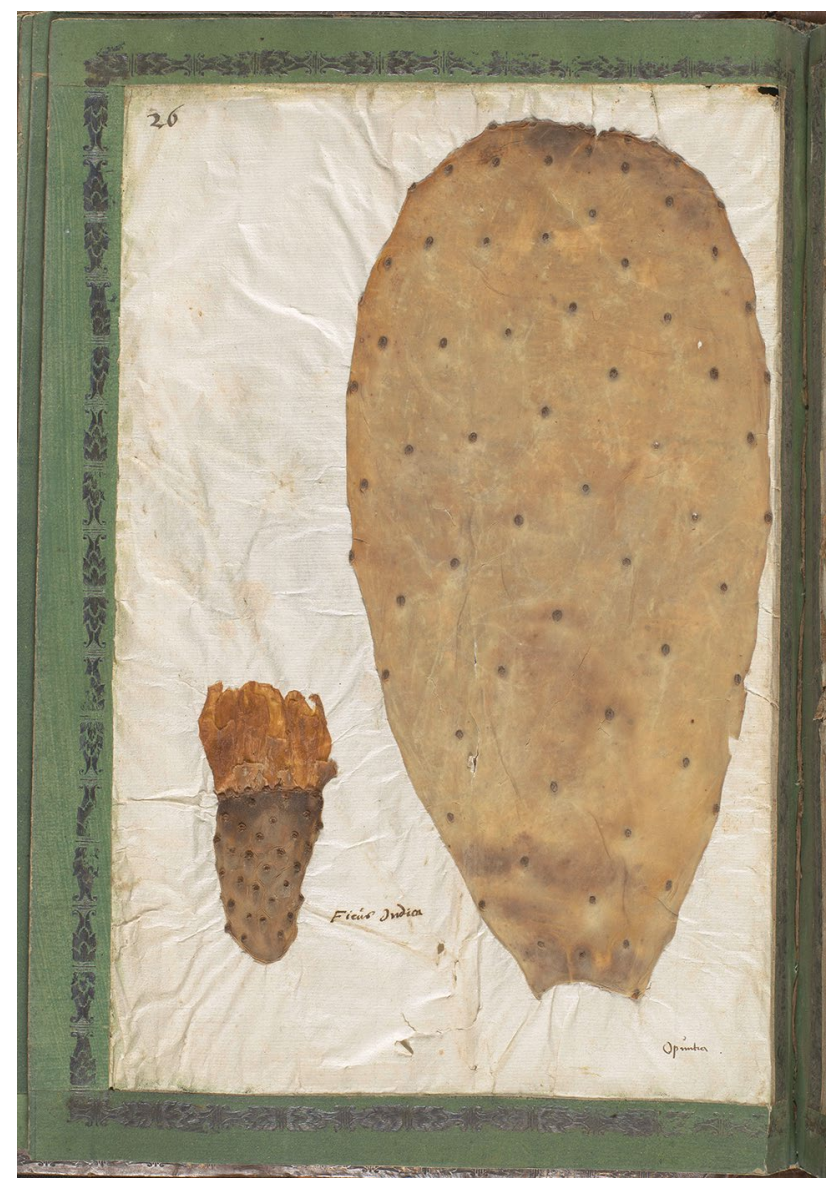

Fig. 6 Specimen of prickly pear, Opuntia ficus-indica (L.) Mill., from the first book herbarium (S. France, 1560-1562)

specimens from Tuscany in the fifth volume of his herbarium (Soldano 2002). One specimen identified as $O$. ficus-indica appears also in Erbario A, a sixteenth century Italian book herbarium of uncertain origin (Penzig 1905; Stefanaki et al. 2019). Unlike the rich record of prickly pear from sixteenth century Italy, no information could be found in literature about France. To our knowledge, the Rauwolf specimen of O. ficus-indica, dated 1560-1562, is the oldest surviving French specimen of prickly pear and the earliest evidence of occurrence of this invasive plant in France. Today this species is locally naturalized in continental S. France, in Côte d'Azur and Albères (Tison and de Foucault 2014). Another sixteenth century specimen of prickly pear, dated c. 1577-1624, is included in the Swiss herbarium of Caspar Bauhin (online available at herbarium.unibas.ch).

\subsection{Handwritings and Rauwolf's botanical network in the $1560 \mathrm{~s}$}

The early book herbaria of Rauwolf are not only an important source of early botanical records. They also provide
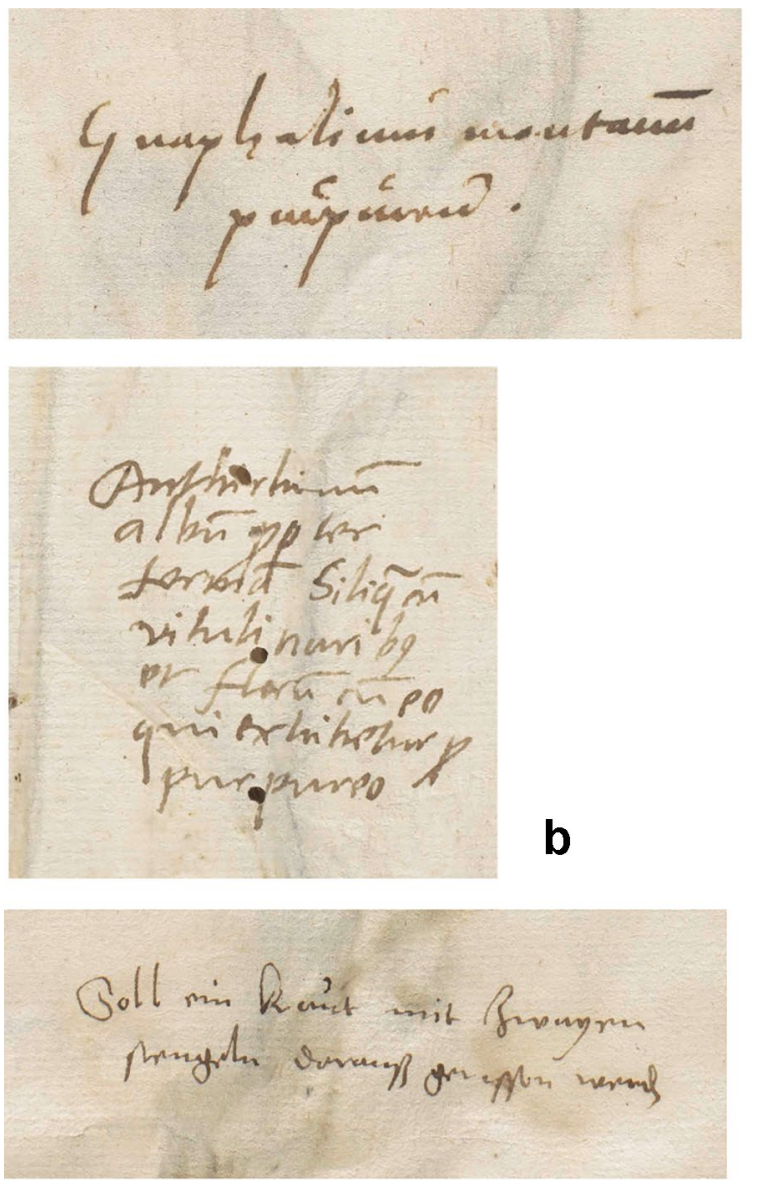

C

Fig. 7 Examples of handwritings from the three book herbaria: Leonhard Rauwolf (A); Johann Bauhin (B); Leonhart Fuchs (C)

information on sixteenth century professional botanical networks, evidenced by the various handwritings present in the three book volumes. We have identified three different hands that contributed plant names and annotations, of which one was matched to Rauwolf (Fig. 7A) in his autograph letters to Camerarius and Clusius from 1579 and 1584, respectively.

We were surprised to discover that the most frequent handwriting in the first and the second herbarium compiled in France does not belong to Rauwolf himself. The handwriting of Rauwolf appears in less than one-fifth of the plant specimens contained in these two volumes. We attributed this dominant handwriting of the French book herbaria to Johann Bauhin (Figs. 7B, 8; Online Resource 1), classmate of Rauwolf in Montpellier and his companion during field excursions in S. France (Longeon 1976). Although we noticed considerable diversity within the handwriting of Bauhin in his autograph letters, and also within the handwriting in the first and the second herbarium herein identified as Bauhin's, remarkable similarity was observed in the overall hand's style, in many individual capital and small characters and in the link between characters (Fig. 8, Online 
Fig. 8 'Unknown' handwriting in the first and the second book herbarium (a); Johann Bauhin's handwriting in his autograph letter to Joachim Camerarius from 09 July 1597, University Library of Erlangen-Nuremberg, urn:nbn:de:bvb:29-bv043 548830-1 (b)
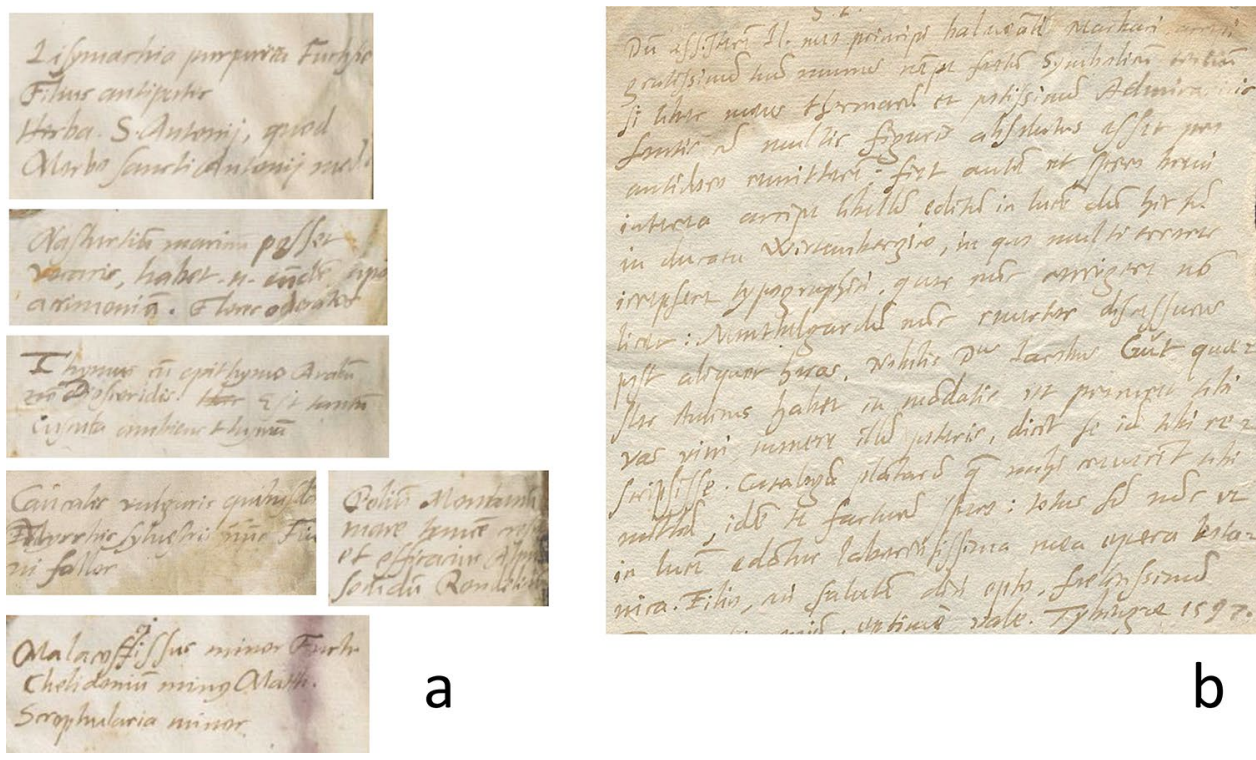

Resource 1). The only noteworthy dissimilarity we could observe between the book herbaria and the autograph letters was in character ' $h$ ' (Online Resource 1). Legré (1900) had probably also noticed the presence of another handwriting than that of Rauwolf but not to its actual extent, since he referred to many of Bauhin's annotations as if they belonged to Rauwolf. Closer observations, however, leave no doubt that the two handwritings, identified herein as Rauwolf's and Bauhin's, belong to two different hands (Fig. 7A, B).

This new finding about the relationship between Rauwolf and Bauhin clearly demonstrates an active involvement of the young Swiss fellow student in the making of the early book herbaria of Rauwolf. Bauhin wrote most of the Latin plant name(s) appearing next to the specimens of the first and the second herbarium, and for some plants, he also noted down French and German names in Gothic characters. Here and there, he even added remarks on a plant's morphology, biology, habitat or abundance. Bauhin's thorough annotations show his emerging scholarly interest in the study of plants, which would later be revealed through his Historia Plantarum Universalis, Bauhin's posthumously published opus magnum which described thousands of plants. It is remarkable that Rauwolf hardly ever mentioned Bauhin in his later life, at least he did not in his surviving mail correspondence. On the other hand, Bauhin referred to Rauwolf in several plant descriptions in Historia Plantarum Universalis (Bauhin and Cherler 1650-1651), showing his esteem for his old field companion.

The making of a plant collection was a personal practice that all students of medicine would learn from Rondelet in Montpellier. It is, therefore, remarkable that the collection of Rauwolf has such an evident contribution of another student. Therefore, it can be assumed with good reasons that in France, Rauwolf was still a beginner in botany and asked for the help of his classmate Bauhin, while later in Italy, he had advanced enough to prepare the third herbarium by himself. In the third herbarium, the dominant handwriting belongs to Rauwolf and the handwriting of Bauhin is absent. It is also likely that Bauhin did not accompany Rauwolf in his plant collections around N. Italy, although he also lived in Italy in 1563 (Cristofolini et al. 1993) and did join Rauwolf in the journey of return from Italy, as we know that the two signed together the Liber amicorum of Gessner in Zurich in May 1563 (Durling 1965). By the time that Rauwolf headed to the Near East, he had become a master in methodically identifying and describing plants, even exotic ones; the plant names appearing in his travelogue and fourth book herbarium are botanically and lexicologically flawless (Walter et al. 2021). Bauhin also had his own herbarium, which he had presented to Conrad Gessner (see Gessner to Benedictus Aretius, 24 November 1565, www.aerztebriefe.de/id/00016 205). These plants may now be part of the herbarium of his younger brother Caspar Bauhin kept in Basel (Cristofolini et al. 1993).

A third handwriting (Fig. 7C) of small spidery letters that frequently appears in all three herbaria has been noticed also by previous authors, who attributed it to either Carolus Clusius (Legré 1900) or Leonhart Fuchs (Ganzinger 1963). Based on our comparison with autograph letters of both botanists, this handwriting was undoubtedly matched with Fuchs' characteristic handwriting. It appears in a total of 162 plant specimens, which is a bit more than the 148 cases that Ganzinger (1963) had observed. Among Fuchs' annotations, the indication 'Soll gerissen werden' to illustrator Jerg Ziegler appears in 56 of the herbarium folia. Most of the plants that Fuchs indicated to be illustrated are contained in the first and the second herbarium (20 and 27, respectively) compiled in France. Only nine plants were indicated to be illustrated 
in the Italian third herbarium. Therefore, it was primarily the French plants that were of interest to Fuchs, rather than those collected in Italy, the latter having been frequently botanized by $\mathrm{N}$. European sixteenth century naturalists.

Observing the numerous annotations of Fuchs in the book herbaria, it becomes evident that the famous German botanist showed a rather disrespectful attitude to the young and yet unknown Rauwolf. Fuchs 'corrected' Rauwolf's herbaria as if they were a student essay, even crossing out some of Rauwolf's and Bauhin's plant names, replacing them with his own suggestions and adding numerous annotations not addressed to Rauwolf but to Fuchs' illustrator. Moreover, Fuchs never officially named Rauwolf's herbaria as a material source for his illustrated manuscript, although he did mention in 1563 to Camerarius that he included Rauwolf's material in his manuscript (Meyer et al. 1999). Even worse, many suggestions of plant names that Fuchs provided were actually less accurate than the names originally given by Rauwolf and Bauhin. This can be shown for example in two specimens of marigold (Tagetes erecta L.), another American species that Rauwolf collected in Italy (third herbarium, folia 19-20). Rauwolf's reasonable name 'Tagetis' was crossed out and corrected to 'Betonica' by Fuchs. More examples of such inaccurate corrections are provided by Legré (1900; erroneously referring to Clusius). Nevertheless, Rauwolf humbly accepted this and most of the suggestions of his former teacher, discarding his own plant names when he later wrote the book indices.

Legré (1900) incorrectly attributed Fuchs' handwriting in the Rauwolf herbaria to Carolus Clusius, claiming as evidence Clusius' handwriting in his personal archival annotations found on his preserved letters at the Leiden University Library. Based on our observations, the handwriting of Clusius is not present in any of the three book volumes. Legré's hypothesis that Clusius annotated the herbaria is also historically flawed. When Clusius visited Augsburg in 1563, he was not yet a famous botanist, so it was unlikely that Rauwolf would seek a meeting with him to show him his plant collection. Moreover, in 1582, Clusius reported in a letter to Joachim Camerarius that he did not know Rauwolf personally yet (Walter et al. 2021). Clusius, like Rauwolf, had studied botany in Montpellier with Rondelet, it is, therefore, unlikely that a good botanist with knowledge of the local flora would have made erroneous plant identifications. On the other hand, Fuchs, although also a good botanist, was not a well-traveled man and he was unfamiliar with the Mediterranean flora as he had never been to the south. This may be the reason why he desired that plants from Rauwolf's herbaria were illustrated for his herbal in preparation.

Rauwolf must have shown his freshly compiled plant collection to Gessner too during his stay in Zurich in 1563 (Walter et al. 2021). But although the name of Gessner as author of plant names does appear a few times in the book volumes, written by the hand of Bauhin or Rauwolf, Gessner himself did not make any annotations in Rauwolf's herbaria, as his handwriting could not be found in any of the three volumes.

\subsection{Watermarks and the story of making of Rauwolf's early book herbaria}

Various types of paper can be distinguished in the three book herbaria (Table 2). The first and the second herbarium compiled in France appear to have paper with the same three watermarks: the types 'fish \& crown', 'hand/glove \& flower', and 'helmet-like' (Table 2; Fig. 9). Good matches for these watermarks could not be found in the Bernstein 'Memory of Paper' watermark catalogue. The third herbarium compiled in Italy shows a very different paper composition, including the watermark types 'serpent \& coat of arms', 'triple mountain \& cross', and 'letter B \& trefoil' (Table 2; Fig. 9). Only for the 'triple mountain \& cross' type, corresponding watermarks were found in the Bernstein catalogue. The most similar ones, registered in paper used in the city of Padua in 1553-1554 (see e.g., https://www.wasserzeichen-online. de/wzis/detailansicht.php?id=34847), appear to confirm an Italian origin. Padua is one of the places that Rauwolf visited in 1563 (Table 1), and it seems likely that he acquired this paper there. Paper with other types of watermarks is present in the books' indices and title pages. These differences in the paper and watermark types show that Rauwolf was gradually buying stacks of paper while progressively enlarging his collection. He apparently went to Italy with some paper leftover from France (the one with the 'helmet-like' watermark type, present in all three book herbaria, and the one

Table 2 Watermark types present in the three book herbaria. Watermarks of the numbered folia are indicated with ' $x$ '

\begin{tabular}{llll}
\hline Watermark & \multicolumn{2}{l}{ Herbarium } & \\
\cline { 2 - 4 } & One & Two & Three \\
\hline 'Fish \& crown' & $\mathrm{x}$ & $\mathrm{x}$ & \\
'Hand/glove \& flower' & $\mathrm{x}$ & $\mathrm{x}$ & $\mathrm{x}$ \\
'Helmet-like' & $\mathrm{x}$ & $\mathrm{x}$ & $\mathrm{x}$ \\
'Heraldic eagle \& crown'b & & $\mathrm{x}$ & $\mathrm{x}$ \\
'Serpent \& coat of arms' & & $\mathrm{x}$ \\
'Triple mountain \& cross' & & $\mathrm{x}$ \\
'Letter B \& trefoil' & & & \\
'Letters AR \& lily' & Index, sheet & Index, title page & \\
& after title & & \\
'Heraldic eagle, small'b & page & & Title page \\
'Heraldic eagle \& nimbus'b & & & \\
\hline
\end{tabular}

Examples of the watermarks are shown in Fig. 9

${ }^{\text {a }}$ Several variants, ${ }^{\text {bShape not clear }}$ 

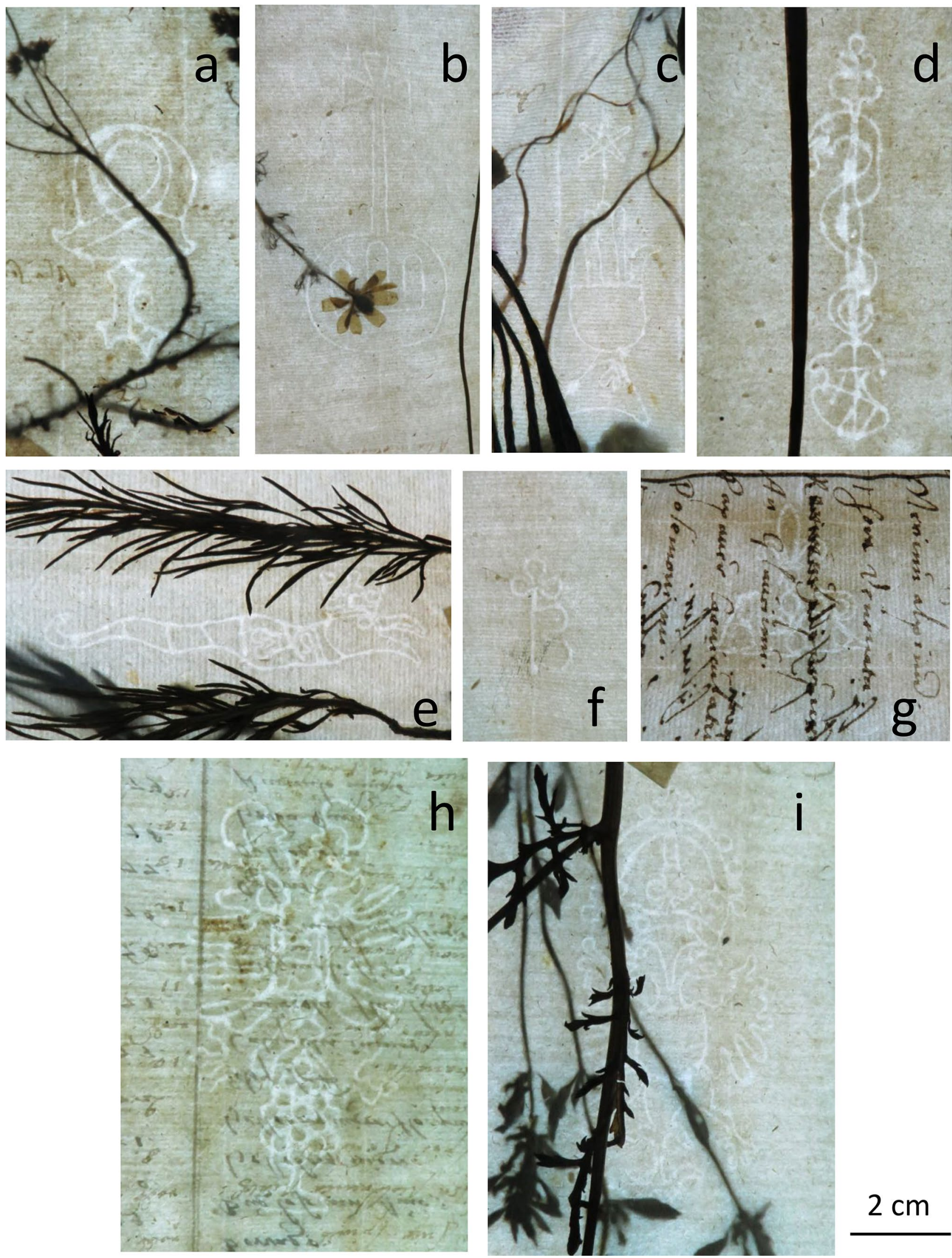

$2 \mathrm{~cm}$ 
4Fig. 9 Watermarks present in the book herbaria: 'Helmet-like', 3:910 (a); 'Triple mountain \& cross', 3:151-152 (b); 'Hand/glove \& flower', 2:175-176 (c); 'Serpent \& coat of arms', 3:41-42 (d); 'Fish \& crown', 2:119-120 (e); 'Letter B \& trefoil', 3:205-206 (f); 'Letters AR \& lily', 2:index (g); 'Heraldic eagle \& nimbus', 3:index (h); 'Heraldic eagle \& crown', 3:45-46 (i)

with the 'heraldic eagle \& crown' watermark, present in the second and the third herbarium; Table 2), and continued to gradually acquire more stacks of paper in Italy while progressing the plant collections. The books' title pages, indices, and endpapers have also paper of different quality and watermarks (Table 2), a fact that shows that the title pages, indices, and binding were probably made at a later stage.

For several years, Rauwolf must have kept the plants he had collected in France and Italy on loose paper sheets. The indices found at the back of the three herbaria, all written by the hand of Rauwolf, were probably made around 1564, as Rauwolf has written in the index of the second herbarium. In that year, Rauwolf was still fresh back in Augsburg, unmarried and without employment. He probably had hardly to deal with patients, as newly graduated doctors were generally avoided. Rauwolf may, therefore, have had not enough money to have his book herbaria bound, but probably plenty of time to put the plants in order and prepare the indices. Although Rauwolf's early book herbaria are smaller in size and less luxurious than the masterpiece fourth herbarium, all four books share the same calligraphic style in the title pages, numbered in series as Erste, Ander, Dritte, and Vierte Kreütterbuch, similarities that indicate that the four herbaria were probably bound in the same period. The title pages of the four books were produced by distinguished specialists. Augsburg, where Rauwolf lived, was one of the richest cities in Germany, with excellent craftsmen and artists available. The four books were probably not bound before 1571, because in the title pages Rauwolf is named as the city doctor of Augsburg, a position that he only acquired in 1571. Interestingly, on 30 August 1577, Rauwolf declared that he was still rearranging the plants that he had collected in the Orient and glued them in the 'right order' on paper (www.aerztebriefe.de/id/00000167). Rauwolf worked on his travelogue until 1582. His decision in 1584 to sell his herbaria due to financial difficulties makes it unlikely that he would have had the books rebound in a time-consuming and expensive process. We, therefore, suggest that all four volumes were probably bound between late 1577 and 1582 .

\section{Conclusion}

The early book herbaria of Leonhard Rauwolf are a valuable source of information on Early Modern students of medicine botanizing in the field in France and Italy. They contain some of the earliest records of useful plants, such as tobacco and prickly pear discussed herein, adding to our knowledge of introduction of these exotic species to Europe. This collection is also an important source of information on professional networking of sixteenth century naturalists. Studying the different handwritings present in the three books, we follow the relationships of Rauwolf with other famous sixteenth century botanists. The study of watermarks and handwritten texts in Rauwolf's early book herbaria allowed us to elucidate the making process of this collection, demonstrating the benefits of interdisciplinary research when studying historic plant collections. The remarkable number of watermarks present in the book herbaria, to which no similar ones could yet be found in the existing watermark databases, shows the value of Rauwolf's early book herbaria also for the study of the history of paper. The next step of our research is the botanical inventory of Rauwolf's early book herbaria, expected to reveal more of the botanical importance of this precious historical plant collection.

Supplementary Information The online version contains supplementary material available at https://doi.org/10.1007/s12210-021-01012-1.

Acknowledgements We thank Kasper van Ommen for his hospitality at the Scaliger Institute and access to the Special Collections of Leiden University Library; Christel Schollaardt (Naturalis Biodiversity Center) and Tim Huisman (Boerhaave museum) for allowing physical examination of the Rauwolf herbaria; Nicolas Aubert and Pascaline Todeschini (Bibliothèque Universitaire Historique de Médecine, Université de Montpellier) for providing the image of Rauwolf's matriculation oath; and Cecile Aupic (Museum National Histoire Naturelle) for providing information on the Jehan Girault herbarium.

Author contributions Conceptualization: AS and TvA; methodology: AS, TvA, HP, and TW; formal analysis and investigation: AS, TW, HP, and $\mathrm{AB}$; writing - original draft preparation: AS, HP, and TW; writing - review and editing; AS, TW, TvA, HP, and AB; funding acquisition: TvA, AS, and TW.

Funding This study was financed by the Van de Sande foundation. Research on early modern physicians' correspondences in the Germanspeaking area was funded by the Bavarian Academy of Sciences and Humanities (http://www.Arztebriefe.de).

Availability of data and material All data produced in this research are included in the manuscript and its additional file.

Code availability Not applicable.

\section{Declarations}

Conflict of interests The authors declare that no conflict of interest exists.

Consent to participate Not applicable.

Consent for publication Not applicable.

Ethics approval Not applicable. 
Open Access This article is licensed under a Creative Commons Attribution 4.0 International License, which permits use, sharing, adaptation, distribution and reproduction in any medium or format, as long as you give appropriate credit to the original author(s) and the source, provide a link to the Creative Commons licence, and indicate if changes were made. The images or other third party material in this article are included in the article's Creative Commons licence, unless indicated otherwise in a credit line to the material. If material is not included in the article's Creative Commons licence and your intended use is not permitted by statutory regulation or exceeds the permitted use, you will need to obtain permission directly from the copyright holder. To view a copy of this licence, visit http://creativecommons.org/licenses/by/4.0/.

\section{References}

Bauhin J, Cherler JH (1650-1) Historia plantarum universalis, nova, et absolutissima, cum consensu et dissensu circa eas. 3 vols. Yverdon. http://mdz-nbn-resolving.de/urn:nbn:de:bvb:12-bsb11 394430-7

Baumann B, Baumann H, Baumann-Schleihauf S (2001) Die Kräuterbuch-Handschrift des Leonhart Fuchs. Ulmer, Stuttgart

Callmer C (1973) Queen Christina's Herbaria. In: Sandgren F (ed) Otium et Negotium: studies in onomatology and library science presented to Olof von Feilitzen. PA Norstedt \& Söner, Stockholm, pp 32-37

Camus J, Penzig O (1885) Illustrazione del ducale Erbario Estense conservato nel R. Archivio di Stato in Modena. GT Vincenzi e nipoti, Modena

Caruel T (1858) Illustratio in hortum siccum Andreae Caesalpini. Le Monnier, Florence

Casas A, Barbera G (2002) Mesoamerican domestication and diffusion. In: Nobel PS (ed) Cacti: biology and uses. University of California Press, Berkeley, Los Angeles, London, pp 143-162

Chiovenda E (1927) Un antichissimo Erbario anonimo del Museo Botanico di Firenze. Annali Di Botanica 17:119-139

Cooper A (2007) Inventing the Indigenous. Local Knowledge and Natural History in Early Modern Europe. Cambridge University Press, Cambridge

Cristofolini G, Mossetti U, Bonfiglioli C (1993) Pre-linnean herbaria in Bologna: some newly discovered collections from the time of Ulisse Aldrovandi. Webbia 48:555-565

Dannenfeldt KH (1968) Leonhard Rauwolf: Sixteenth-century physician, botanist and traveler. Harvard University Press, Cambridge, Mass. https://doi.org/10.4159/harvard.9780674331105

De Toni E (1940) Pietro Antonio Michiel I Cinque libri di piante, Codice Marciano. Carlo Ferrari, Venezia

Durling R (1965) Conrad Gesner's 'Liber amicorum' (15551565). Gesnerus 22:134-159. https://www.e-periodica.ch/digbib/ view?pid=ges-001\%3A1965\%3A22\%3A\%3A3\#148

Eggli U, Wyder M, Nyffeler R (2018) Johannes Kentmann, Conrad Gessner und die Einführung des Feigenkaktus in Europa im 16. Jahrhundert. Bauhinia 27:47-59

Egmond F (2018) Into the Wild: Botanical Fieldwork in the Sixteenth Century. In: MacGregor A (ed) Naturalists in the field: Collecting, Recording and Preserving the Natural World from the Fifteenth to the Twenty-First Century. Leiden, Boston, Brill, pp 166-211

Ganzinger K (1963) Rauwolf und Fuchs. Ein Beitrag zur Geschichte der Botanik im 16. Jahrhundert. Veröffentlichungen der Internationalen Gesellschaft für Geschichte der Pharmazie N.F. 22:23-42

Ghorbani A, De Boer HJ, Maas PJM, van Andel TR (2017) The typification of two Linnaean plant names based on illustrations published by Leonhard Rauwolf in 1583. Taxon 66:1204-1207

Ghorbani A, Wieringa JJ, Boer HJD, Porck H, Kardinaal A, van Andel TR (2018) Botanical and floristic composition of the Historical
Herbarium of Leonhard Rauwolf collected in the Near East (1573-1575). Taxon 67:565-580

Herde S, Walter T (2010) Neues zur Biographie des Augsburger Arztes und Orientreisenden Leonhard Rauwolf (1535?-1596). Sudhoffs Archiv 94:129-156

Kentmann J (1549) Plantarum atque animantium numquam hactenus impressarum imagines, partem in Italia; partem in aliis nationibus collectae, \& ad vivum expressae inque III libros digestae; Herzogin Anna Amalia Bibliothek Weimar, Fol 323 [Manuscript]. https://haab-digital.klassik-stiftung.de/viewer/resolver?urn=urn: nbn:de:gbv:32-1-10024299227. Accessed 26 Jun 2021

Kessler HF (1870) Das älteste und erste Herbarium Deutschlands, im Jahre 1592 von Dr Caspar Ratzenberger angelegt: gegenwärtig noch im Königlichen Museum zu Cassel befindlich. Freyschmidt, Kassel. http://mdz-nbn-resolving.de/urn:nbn:de:bvb: 12-bsb11018583-2

Knapp S, Chase MW, Clarkson JJ (2004) Nomenclatural changes and a new sectional classification in Nicotiana (Solanaceae). Taxon 53:73-82

Kusukawa S (2006) The Use of Pictures in the Formation of Learned Knowledge: The Cases of Leonhard Fuchs and Andreas Vesalius. In: Kusukawa S, Maclean I (eds) Transmitting Knowledge: Words, Images, and Instruments in Early Modern Europe. Oxford University Press, Oxford, pp 73-96

Kusukawa S (2012) Picturing the book of nature: Image, Text, and Argument in Sixteenth-Century Human Anatomy and Medical Botany. University of Chicago Press, Chicago, London

Legré ML (1900) La botanique en Provence au XVIe siecle. Léonard Rauwolff. Jacques Raynaudet. Aubertin \& Rolle, Marseille

Lewis RS (2011) Nicotiana. In: Kole C (ed) Wild Crop Relatives: Genomic and Breeding Resources. Springer, Berlin, Heidelberg, pp 185-208

Longeon C (1976) Introduction et notes. In: Gesner C, Vingt lettres a Jean Bauhin fils (1563-1565). Publications de l'Universite de Saint-Etienne, Saint-Etienne

Meyer FG, Trueblood EWE, Heller JL (1999) The great herbal of Leonhart Fuchs: De historia stirpium commentarii insignes, 1542. Stanford University Press, Stanford

Ogilvie BW (2006) The science of Describing: Natural History in Renaissance Europe. University of Chicago Press, Chicago, London

Penzig O (1905) Illustrazione degli Erbarii di Gherardo Cibo. In: Penzig O (ed) Contribuzioni alla storia della botanica. Hoepli, Milano, pp 1-237

Rauwolf L (1583) Aigentliche Beschreibung der Raiß [...] inn die Morgenländer. Willers, Laugingen. http://mdz-nbn-resolving. de/urn:nbn:de:bvb:12-bsb10206788-9 and http://mdz-nbn-resol ving.de/urn:nbn:de:bvb:12-bsb11212047-7

Seybold S (1990) Luca Ghini, Leonhard Rauwolff und Leonhart Fuchs. Über die Herkunft der Aquarelle im Wiener Krauterbuchmanuskript von Fuchs. Jahreshefte Der Gesellschaft Fur Naturkunde in Württemberg 145:239-264

Soldano A (2000) La provenienza delle raccolte dell'erbario di Ulisse Aldrovandi, Volumi I e II. Atti Dell' Istituto Veneto Di Scienze, Lettere Ed Arti, Classe De Scienze Fisiche, Matematiche e Naturali 158:1-246

Soldano A (2001) La provenienza delle raccolte dell'erbario di Ulisse Aldrovandi. Volumi III e IV, Atti Dell' Istituto Veneto Di Scienze, Lettere Ed Arti, Classe De Scienze Fisiche, Matematiche e Naturali 159:1-215

Soldano A (2002) La provenienza delle raccolte dell'erbario di Ulisse Aldrovandi, Volumi V-VI-VII. Atti Dell' Istituto Veneto Di Scienze, Lettere Ed Arti, Classe De Scienze Fisiche, Matematiche e Naturali 160:1-248

Soldano A (2003) La provenienza delle raccolte dell'erbario di Ulisse Aldrovandi, Volumi VIII-IX-X-XI. Atti Dell' Istituto 
Veneto Di Scienze, Lettere Ed Arti, Classe De Scienze Fisiche, Matematiche e Naturali 161:1-241

Soldano A (2004) La provenienza delle raccolte dell'erbario di Ulisse Aldrovandi, Volumi XII-XIII-XIV. Atti Dell' Istituto Veneto Di Scienze, Lettere Ed Arti, Classe De Scienze Fisiche, Matematiche e Naturali 162:1-248

Soldano A (2005) La provenienza delle raccolte dell'erbario di Ulisse Aldrovandi, Volume XV. Atti Dell' Istituto Veneto Di Scienze, Lettere Ed Arti, Classe De Scienze Fisiche, Matematiche e Naturali 163:1-171

Speta F, Grims F (1980) Hieronymus Harder und sein „Linzer“ Herbarium aus den Jahre 1599. Kataloge des Ö̈. Landesmuseums 105, zugleich Linzer Biologische Beiträge 12:307-330

Stech M, van Andel T, Aptroot A, Bertin A, Stefanaki A (2018) Bryophytes and lichens in 16th-century herbaria. J Bryol 40:99-106

Stefanaki A, van Andel TR (2021) Mediterranean aromatic herbs and their culinary use. In: Galanakis C (ed) Aromatic herbs in foods. Bioactive compounds, processing, and applications. Elsevier, Amsterdam. https://doi.org/10.1016/B978-0-12-822716-9. 00003-2

Stefanaki A, Thijsse G, van Uffelen G, Eurlings M, van Andel TR (2018) The En Tibi herbarium, a $16^{\text {th }}$-century Italian treasure. Bot J Linn Soc 187:397-427

Stefanaki A, Porck H, Grimaldi IM, Thurn N, Pugliano V, Kardinaal A, Salemink J, Thijsse G, Chavannes-Mazel C, Erik K, van Andel TR (2019) Breaking the silence of the 500-year-old smiling garden of everlasting flowers: The En Tibi book herbarium. PLoS ONE 14:e0217779. https://doi.org/10.1371/journal.pone.0217779

Stübler E (1928) Leonhart Fuchs, Leben und Werk. Verlag der Münchner Drucke, München
Thijsse G (2016) Tusschen pampier geleyt: Ontstaan, verspreiding en gebruik van de vroegste herbaria. In: IJpelaar L, Chavannes-Mazel CA (eds) De groene Middeleeuwen. Duizend jaar gebruik van planten (600-1600). Lecturis BV, Eindhoven, pp 64-93

Tison JM, de Foucault B (2014) Flora Gallica: flore de France. Biotope, Mèze

Vicentini CB, Buldrini F, Romagnoli C, Bosi G (2020a) Tobacco in the Erbario Estense and other Renaissance evidence of the Columbian taxon in Italy. Rend Fis Acc Lincei 31:1117-1126

Vicentini CB, Buldrini F, Bosi G, Bonazza M, Romagnoli C (2020b) Carte verdi nell'Archivio di Stato di Modena: l'Erbario Estense, foglie tra i fogli, un rebus, un progetto. Parte II. Atti Mem Accad Ital Stor Farm 37:125-140

Walter T (2009) Eine Reise ins (Un-)Bekannte. Grenzräume des Wissens bei Leonhard Rauwolf (1535?-1596). NTM. Zeitschrift Für Geschichte Der Wissenschaften, Technik Und Medizin 17:359-385

Walter T, Ghorbani A, van Andel TR (2021) The emperor's herbarium: The German physician Leonhard Rauwolf (1535?-96) and his botanical field studies in the Middle East. History of Science, https://doi.org/10.1177/00732753211019848

Publisher's Note Springer Nature remains neutral with regard to jurisdictional claims in published maps and institutional affiliations. 